\title{
IMPLEMENTASI MAQĀṢID AL-SHARİ'AH DALAM HUKUM EKONOMI ISLAM
}

\author{
Syufa'at
}

STAIN Purwokerto

e-mail: daniasyafaat@gmail.com

\begin{abstract}
The objective revelation of Islamic law is to create public interest (mașlahat), both individually and collectively. The public interest that mentioned in Islamic law is the true goodness, not the pseudo benefit which influenced human desires. The Public interest here includes physical and spiritual. The public interest that intended by Islamic law is the goodness in this life and in the hereafter, not solely in the world live. maslahah in the Shariah perspective is based on five principles called al-mabādi'al-khamsah or al-ușūl alkhamsah namely: keeping religion (hifz al-dīn), keeping the soul (hifz al-nafs), keeping mind (hifz al-'aql), keeping property (hifz al-māl), and keeping descent (hifz al-nasl). Maqāșid al-shari'ah implementation of some economic problems is to answer the reality of modern society to face the challenges of basic needs such as clothing, food, shelter, health, education, employment, sanitation, energy, transport and information. Crucial needs of modern man is the spiritual and ethical, because modern society only measure the welfare just from the outer side only, that is to meet the needs according to the principle of utility and pragmatism.
\end{abstract}

\section{[]}

Tujuan disyari'atkan hukum Islam adalah untuk menciptakan kemaslahatan manusia, baik secara individu maupun kolektif dalam masyarakat. Kemaslahatan yang dimaksud dalam hukum Islam adalah kemaslahatan yang sejati, bukan kemaslahatan semu yang dipengaruhi hawa nafsu belaka. Kemaslahatan disini meliputi kemaslahatan jasmani dan kemaslahatan rohani atau spiritual. Kemaslahatan yang ditunjuk hukum Islam adalah kemaslahatan di dunia dan di akhirat bukan semata mata di dunia. Kemaslahatan yang menjadi orientasi syari'ah didasarkan pada lima prinsip kepentingan manusia yang disebut dengan al-mabādi'al-khamsah atau al-ușūl al-khamsah meliputi: menjaga agama (hifz al-dīn), menjaga jiwa (hifź al-nafs), menjaga akal (hifz̦ al-'aql), menjaga harta (hifż al$m \bar{a})$, menjaga keturunan (hifž al-nasl). Implementasi maqūṣid al-sharīah terhadap beberapa permasalahan ekonomi adalah menjawab realitas masyarakat modern menghadapi tantangan kebutuhan dasar (human basic needs) kebutuhan sandang, pangan, papan, kesehatan, pendidikan, lapangan kerja, sanitasi, energi, transportasi dan informasi. Kebutuhan krusial manusia modern yang harus dipenuhi adalah spiritual dan etika, karena masyarakat modern mengukur kesejahteraan hanya dari segi lahiriah yakni memenuhi kebutuhan asas manfaat (utility) dan pragmatisme.

Keywords: maqāṣid al-sharīah, ilmu ekonomi Islam, maslahat, mu’amalat

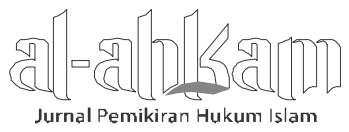


Syufa'at

\section{Pendahuluan}

Pembicaraan mengenai maqāṣid al-sharī'ah di era sebelum al-Shātibī hanya dapat diidentifikasi secara implisit dalam tema-tema kajian illatal-ḥukm (alasan hukum) dan maslahat. 'Illat yang diartikan dengan suatu perkara yang jelas dan tegas yang menjadi alasan ditetapkannya hukum menjadi tema kajian yang menarik ketika dihubungakan dengan kajian maslahat. Sementara kajian 'illat ini juga memasuki wilayah kajian teologi ketika dihubungkan dengan pertanyaan apakah hukum yang ditetapkan Tuhan itu berdasarkan 'illat (kausa) tertentu atau tidak. Menjawab pertanyaan tersebut, pasti melibatkan alasan-alasan teologis dan hukum. Ringkasnya dapat dikatakan bahwa semua ahli ușūl al-fiqh sepakat tentang tujuan akhir dari hukum adalah satu yaitu maslahat atau kebaikan dan kesejahteraan umat manusia.

Pengenalan dan pembahasan tentang konsep maqāṣid al-sharī'ah telah dimulai dari Imām al-Ḥaramayn al-Juwaynī. Beliau dapat dikatakan sebagai ahli ușūl al-fiqh pertama yang menekankan pentingnya memahami maqāṣid al-sharī’ah dalam menetapkan hukum Islam. Ia secara tegas menyatakan bahwa seseorang tidak mampu menetapkan hukum sebelum benar-benar memahami tujuan Allah mengeluarkan perintah dan larangan. Lebih jauh ia mengelaborasi maqāṣid al-sharīah tersebut dalam hubungannya dengan 'illat dan aṣl yang dapat dikategorikan ke dalam lima bagian, yaitu așl yang masuk dalam kategori ḍaūriyyāt (primer), alhājah al-'āmmah (sekunder), makramāt (tersier), sesuatu yang tidak termasuk kelompok ḍarūriyyāt dan hājiyyāt, dan sesuatu yang tidak termasuk ke dalam ketiga kelompok sebelumnya. Singkatnya, al-Juwaynī membagi aṣl atau tujuan tashri' itu menjadi tiga macam yaitu ḍarūriyyāt, hājiyyāt dan makramāt (tậsiniyyāt). ${ }^{1}$

Pemikiran al-Juwaynī tersebut dikembangkan oleh muridnya yakni al-Ghazālī. Beliau menjelaskan maksud syariat dalam kaitannya dengan pembahasan almunāsabāt al-mașlahiyyāt dalam qiyas dan dalam kesempatan yang lain ia menjelaskannya dalam tema istiṣlāh. Maslahat menurut al-Ghazālī adalah memelihara agama, jiwa, akal, keturunanan dan harta. ${ }^{2}$ Kelima macam maslahat di atas berada pada skala prioritas dan urutan yang berbeda jika dilihat dari sisi

\footnotetext{
1Abū al-Ma'ālī al-Juwaynī, al-Burhān fí Ușūl al-Fiqh (Beirut: Dār al-Kutb al-'Ilmiyyah, 1997).

${ }^{2}$ Abū Hāmid al-Ghazālī, al-Mustașfā min 'Ilm al-Ușūl Oedah: Sharīkat al-Madīnah al-Munawwarah li 'l-Tibā'ah, t.th.).

$144 \|$ Volume 23, Nomor 2, Oktober 2013

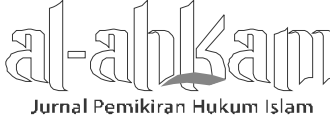


tujuannya yaitu peringkat primer, sekunder dan tersier. Dari keterangan tersebut terlihat bahwa maqāṣid al-sharīah sudah mulai menampakkan bentuknya.

Pemikir dan ahli hukum Islam selanjutnya yang membahas secara khusus maqāṣid al-sharī’ah adalah 'Izzuddīn ibn 'Abd al-Salām³ dari kalangan Syafi'iyyah. Ia lebih banyak menekankan dan mengelaborasi konsep maslahat secara hakiki dalam bentuk menarik maslahat dan menolak mafsadat. Menurutnya, maslahat keduniaan tidak dapat dilepaskan dari tiga tingkatan urutan skala prioritas, yaitu ḍarūriyyāt, hājizyyāt dan takmīlāt atau tatimmāt. Lebih jauh lagi ia menyebutkan bahwa taklīf (penetapan hukum) harus bermuara pada terwujudnya kemaslahatan manusia baik di dunia maupun di akhirat. Berdasarkan penjelasan ini dapat dikatakan bahwa 'Izzuddīn telah berusaha mengembangkan maslahat yang merupakan inti pembahasan dari maqāṣid al-sharīah.

Penjelasan yang sistematis dan secara khusus serta jelas dilakukan oleh alShāțibī dari kalangan Malikiyyah dalam kitabnya al-Muwāfaqāt fi Ușūl al-Sharī'ah. Dalam kitabnya yang terkenal tersebut, ia menghabiskan sepertiga dari bukunya untuk membahas maqāṣid al-sharīah. Tentunya pembahasan tentang maslahat pun menjadi bagian yang sangat penting dalam pembahasannya. Ia secara tegas menyatakan bahwa tujuan utama Allah menetapkan hukum-hukum-Nya adalah untuk terwujudnya kemaslahatan hidup di dunia dan akhirat. Karenanya, taklif harus mengarah pada terealisirnya tujuan hukum tersebut. Setiap suruhan dan larangan yang ada dalam ayat dan hadis tidak terlepas dari upaya memelihara kemaslahatan. Ia juga membagi skala prioritas maslahat manusia menjadi tiga peringkat yaitu ḍarūriyāt, hājizyyāt dan tahsinniyyāt. ${ }^{4}$ Konsep maqāṣid al-sharīah yang dikembangkan oleh al-Shātibī ini sebenarnya tepat diterapkan dalam masalah muamalah seperti jual beli, sewa-menyewa, serikat atau persekutuan usaha. Oleh karena itu, untuk menjawab kebutuhan di atas, para ahli hukum Islam menyarankan agar pengkajian hukum Islam di zaman modern ini hendaknya ditujukan kepada penggalian asas-asas hukum Islam dari aturan-aturan detail yang telah dikemukakan oleh para fuqahä' klasik tersebut.

Dalam rangka mencari basis teori menuju metode yang holistik tersebut, salah satu konsep penting dalam kajian hukum Islam adalah konsep maqāșid al-sharīah,

3'Izzuddīn ibn 'Abd al-'Az̄̄z ibn Abd al-Salām, Qawāi'id al-Aḥkām fi Mașāliḥ al-Anām (t.t.p.: Dār alJayl, t.th).

4al-Shātibī, al-Muwāfaqātfí Ușūl al-Sharīah (Kairo: Mușțaāa Aḥmad, t.th.).

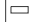

Jurnal Pemikiran Hukum Islam
Volume 23, Nomor 2, Oktober 2013 
Syufa'at

yakni tujuan ditetapkannya hukum dalam Islam. Pentingnya konsep ini, para ahli teori hukum Islam nenetapkan penguasaan pengetahuan tentang maqāṣid alsharīah sebagai salah satu kriteria di samping kriteria lainnya bagi seorang mujtahid dalam melakukan ijtihad. Tulisan ini akan membahas bagaimana implementasi konsep maqāṣid al-sharīah dalam pengembangan ilmu ekonomi Islam.

\section{Definisi Maqāṣid al-Sharīah}

Secara bahasa, maqāṣid al-sharīah terdiri dari dua kata yaitu maqāṣid dan sharī'ah. Maqāṣid adalah bentuk plural dari kata maqasid yang berarti kesengajaan atau tujuan. ${ }^{5}$ Sedangkan kata syari'ah, berasal dari kata al-sharīah dan sinonim dengan kata al-shir'ah. Secara leksikal keduanya berarti jalan menuju mata air. ${ }^{6}$ Ungkapan jalan menuju mata air ini mengandung konotasi keselamatan. Dalam alQur'an kedua kata tersebut dipakai untuk arti agama sebagai jalan lurus yang ditetapkan Allah untuk diikuti oleh manusia agar mendapatkan keselamatan. Dalam perkembangan terakhir, kata syari'ah digunakan untuk merujuk makna pokok-pokok agama dan kadang-kadang merujuk pada aspek pokok agama dan hukum sekaligus. Al-Ash'arī, seorang teolog terkenal secara tegas memakai katakata syari'ah untuk menunjukkan aspek hukum dari agama Islam. Sedangkan alShāțibī mengartikan syari'ah sebagai keseluruhan aturan agama yang mengatur tingkah laku, ucapan dan kepercayaan manusia.7 Pengertian ini menggambarkan syari'ah dalam arti luas yang meliputi aspek hukum dan doktrinal sekaligus. Dengan demikian syari'ah identik dengan agama Islam itu sendiri.

Pengertian syari'ah ini dalam kaitannya dengan maqāṣid al-sharīah akan semakin jelas dengan melihat pengertian yang diberikan oleh M. Syaltut, bahwa syari'ah adalah seperangkat hukum-hukum Tuhan yang diberikan kepada umat manusia untuk mendapatkan kabahagiaan di dunia dan akhirat.8 Kandungan yang demikian secara tidak langsung memuat kandungan maqāṣid al-sharīah dan ini berkorelasi dengan pengertian maqāṣid al-sharīah secara terminologi, sebagaimana terlihat dalam defenisi yang diberikan oleh Wahbah al-Zuhaylī. Ia me767.

${ }^{5}$ Hans Wehr, A Dictionary of Modern Written Arabic (London: Mc Donald \& Evan Ltd, 1980), h.

6Ibn Manẓūr, Lisān al-'Arab (Mesir: Dār al-Mișriyyah li Ta'līf wa 'l-Tarjamah, t.th.), h. 40.

7al-Shātịī, al-Muwāfaqāt fi Ușūl al-Sharīah (Kairo: MușțafāAhmad, t.th.), h. 53.

8M. Shalțūt, Aqīdah wa Sharīah (Kairo: Dār al-Qalam, t.th.), h. 12.

146 || Volume 23, Nomor 2, Oktober 2013

Jurnal Pemikiran Hukum Islam 
maksudkan maqāṣid al-sharīah dengan nilai-nilai dan sasaran-sasaran syariat yang tersirat dalam segenap dan sebagian besar dari hukum-hukum-Nya. Nilainilai dan sasaran-sasaran itu dipandang sebagai tujuan dan rahasia syari'ah yang ditetapkan oleh Shāri' (pembuat syari'ah/Tuhan) dalam setiap ketentuan hukum. ${ }^{9}$ Sementara itu, 'Alal al-Fāsī juga memberikan definisi dengan nada yang sama.10 Dengan kata lain, inti dari konsep maqāṣid al-sharī'ah adalah untuk mewujudkan kebaikan dan menarik kemanfaatan sekaligus menghindari keburukan dan menolak mudarat. Istilah yang sepadan dengan inti maqāșid al-sharī'ah ini adalah kemaslahatan, karena muara dari penetapan hukum Islam adalah kemaslahatan.

Konsep al-maṣlaḥah al-Shātịī melingkupi seluruh bagian syari'ah dan bukan hanya aspek yang tidak diatur oleh naș (teks) saja, Meskipun begitu, pemikiran maslahat al-Shātibī ini tidak seberani dan segarang gagasan maslahat yang dilontarkan oleh ulama kontroversial al-Ṭūfì dari kalangan Hanbaliyyah. Menurutnya, prinsip maslahat dapat membatasi (takhșiș) al-Qur' an, hadis, ijma' jika penerapan al-Qur'an, Sunnah dan Ijma' tersebut menyusahkan manusia. Akan tetapi pemberlakuannya dibatasi hanya dalam bidang muamalah saja.

Berdasarkan berbagai pandangan ulama di atas dapat ditarik sebuah kesimpulan bahwa mereka sepakat tentang tujuan Allah mensyariatkan sebuah hukum adalah untuk memelihara kemaslahatan seluruh manusia, di sisi lain untuk menghindari mafsadat, baik di dunia maupun di akhirat. Tujuan tersebut dicapai melalui taklif, yang pelaksanannya sangat tergantung pada pemahaman sumber hukum utama, al-Qur'an dan hadis. Dalam mewujudkan kemaslahatan manusia di dunia dan akhirat, ada lima hal pokok yang harus dipelihara dan dijaga yaitu agama, jiwa, akal, keturunan dan harta.

\section{Klasifikasi Maqāṣid al-Sharī’ah}

Maqāṣid al-sharīah yang secara substansial mengandung kemaslahatan, menurut al-Shātibī dapat dilihat dari dua sudut pandang. Pertama, maqāṣid al-Shāri' (tujuan Tuhan) dan inilah yang menjadi objek pembahasan ini. Kedua, maqāṣid almukallaf (tujuan mukallaf). Dilihat dari sudut tujuan Tuhan, maqāșid al-sharīah mengandung beberapa aspek pokok, yaitu; 1) tujuan awal dari Shāri' menetapkan

\footnotetext{
9Wahbah al-Zuhaylī, Ușūl al-Fiqh al-Islāmī (Damaskus: Dār al-Fikr, 1986), h. 1017.

10‘Alal al-Fāsī, Maqāṣid al-Sharīah al-Islāmiyyah wa Makārimuhā (t.t.p.: Maktabah al-Wiḥdah al'Arabiyyah, t.th.), h. 3.
}

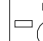

Jurnal Pemikiran Hukum Islam 
syari'ah yaitu kemaslahatan manusia di dunia dan akhirat; 2) penetapan syari'ah sebagai sesuatu yang harus dipahami; 3) penetapan syari'ah sebagai hukum taklif yang harus dilaksanakan.

Penetapan syari'ah guna membawa manusia ke bawah lindungan hukum. Fatḥi al-Dāraynī mengomentari bahwa hukum-hukum tidaklah dibuat untuk hukum sendiri melainkan dibuat untuk tujuan kemaslahatan. Dengan bahasa yang tidak jauh berbeda Abu Zahrah menyatakan bahwa tujuan hakiki hukum Islam adalah kemaslahatan.11 Tidak satu pun hukum yang disyari'atkan baik dalam alQur'an maupun hadis melainkan di dalamnya terdapat kemaslahatan. Pernyataan di atas semakin mempertegas pernyataan al-Shāțibī bahwa sesungguhnya syariat itu bertujuan untuk mewujudkan kemaslahatan manusia di dunia dan akhirat. Semua kewajiban diciptakan dalam rangka merealisasikan kemaslahatan hamba. Tak satupun hukum Allah yang tidak mempunyai tujuan hukum. Dapat dikatakan bahwa kandungan maqāṣid al-sharīah adalah kemaslahatan. Melalui analisis maqāṣid al-sharīah, kemaslahatan tidak hanya dilihat dalam arti teknis belaka, tetapi dalam upaya dinamika dan pengembangan hukum, maqāṣid al-sharīah dilihat sebagai sesuatu yang mengandung nilai filosofis dari hukum-hukum yang disyariatkan Tuhan kepada manusia.

Kamaslahatan yang menjadi tujuan syari'at ini dibatasi dalam lima hal, yaitu agama, jiwa, akal, keturunan dan harta. Setiap hal yang mengandung penjagaan atas lima hal tersebut disebut maslahah dan setiap hal yang membuat hilangnya lima hal disebut mafsadah. Dalam usaha untuk mewujudkan dan mempertahankan lima hal pokok tersebut, maka al-Shātibī membagi kemaslahatan tersebut pada tiga tingkatan, yaitu: ${ }^{12}$ pertama, kemaslahatan ḍarūrī (primer). Kemaslahatan ini adalah kepentingan yang harus ada untuk terwujudnya kemaslahatan dunia akhirat. Apabila kepentingan tersebut tidak ada maka kelangsungan hidup di dunia tidak dapat dipertahankan dan akhirat akan mengalami kerugian eskatologis. Kepentingan ini disebut juga dengan kepentingan primer. Menurut al-Shāțibī, perlindungan terhadap lima kemaslahatan yang telah disebutkan di atas digolongkan ke dalam kategori kemaslahatan ini. Untuk mewujudkan tujuan ini disyariatkan hukuman terhadap orang yang membawa dan menyebarkan ajaran sesat,

11Muhammad Abū Zahrah, Ușūl al-Fiqh, Mesir: Dār al-Fikr al-'Arabī, 1958. Lihat Fathi al-Dāraynī, al-Minhāj al-Ușūliyyah fi Ijtihād bì 'l-Ra'yifí 'l-Tashrīi (Damaskus: Dār al-Kutub al-Hadīth, 1975), h. 28.

12al-Shātịīi, al-Muwāfaqāt, h. 8. 
disyariatkannya qisas yang bertujuan untuk melindungi jiwa, pidana dera untuk minum khamar yang bertujuan melindungi akal, pidana zina yang bertujuan melindungi keturunan, pidana pencurian untuk melindungi kekayaan orang yang merupakan sendi kehidupan manusia.

Kedua, kemaslahatan hājjī (sekunder), yakni kepentingan yang harus ada demi terwujudnya kemaslahatan yang tanpanya kemaslahatan hidup masih dapat dipertahankan, akan tetapi dalam kesulitan dan tidak normal. Contohnya adalah pemberian hak kepada wali mujbir untuk mengawinkan anak di bawah umur. Ini memang bukan merupakan suatu yang bersifat darūrī, akan tetapi sangat dibutuhkan dengan alasan supaya tidak kehilangan jodoh yang sepadan. Ini berbeda halnya dengan hak wali untuk melakukan pengurusan kepentingan pendidikan anak dan pemenuhan kebutuhan lainnya yang berada pada tingkat ḍarūrī karena kebutuhan kepada nafkah dan pemeliharaan yang menyangkut kelangsungan hidup anak.

Ketiga, kemaslahatan tahsinī (tersier), yakni perwujudan kepentingan yang tidak bersifat ḍrūrī dan tidak bersifat hājjī. Dengan kata lain, jika kepentingan ini tidak terwujud, maka tidak menyebabkan kesulitan apalagi mengancam kelangsungan hidup. Sifatnya hanyalah komplementer yang bertujuan untuk mewujudkan praktek ibadah dan muamalat yang lebih baik serta mendorong akhlak dan kebiasaan terpuji. Contohnya adalah pendapat Syafi'i yang melarang jual beli kotoran, anjing, dan semua benda najis. Alasannya dianalogikan dengan jual beli khamar dan bangkai karena najisnya. Penetapan kenajisan kedua benda tersebut rnengisyaratkan pandangan bahwa benda tersebut kurang berguna. Kalau dibolehkan jual beli benda tersebut, berarti memberikan penilaian yang menghargai barang itu dan ini bertentangan dengan syarat-syarat yang menganggapnya sebagai benda tidak berharga.

\section{Cara-cara Mengetahui Maqāṣid al-Sharī’ah}

Sebelum kemunculan al-Shāțibī dengan konsep maqāṣid al-sharīah-nya, mayoritas literatur ușūl al-fiqh hanya mengembangkan pendekatan kaidah-kaidah kebahasaan dalam memahami maksud syara' dengan metode yang berbeda-beda dalam menetapkan maqāṣid tersebut. Mengenai ragam pendekatan metodis untuk menetapkan maqāṣid al-Shātibī membuat kategorisasi tiga aliran. Pertama, aliran zăhiriyyāt yang berpegang teguh pada keterangan syar'i secara harfiyyah (leksikal) untuk menetapkan tujuan syariat sehingga aliran ini menolak penggunaan ra'yi dan qiyas. Kedua, golongan baținiyyāt yang berpegang teguh pada suatu yang ter- 
Syufa'at

sembunyi (rahasia) di balik zāhir teks, terpisah dari teks dan bukan dari teks itu sendiri. Paham ini dikembangkan oleh sekte Syi'ah yang mengklaim kemampuan imam yang mempunyai otoritas ismah (terjaga dari kesalahan) dalam mengetahui rahasia tujuan syariat tersebut. Kelompok ini juga dipegang oleh golongan muta'ammiqīn bī' l-qiyās (fanatis qiyas) yang berpendapat bahwa tujuan syariat terdapat pada makna (inti) yang dapat dicapai melalui penalaran akal sehingga jika terdapat pertentangan antara hasil penalaran akal dengan ketentuan harfiah, maka mereka berpaling dari ketentuan naș dan berpegang pada hasil penalaran. Kelompok ketiga adalah kelompok moderat, yang menggabungkan antara makna penalaran akal dan ketetapan ḥarfiyyah naṣ. Al-Shāțibī masuk ke dalam kelompokini.

Selanjutnya al-Shāṭibī menjelaskan metode pencapaian maqāṣid al-sharīah secara panjang lebar, yang pada pokoknya dapat diringkas sebagai berikut: ${ }^{13}$ pertama, maqāṣid al-sharīah dapat diketahui dari perintah dan larangan Tuhan yang bersifat jelas, keduanya menunjukkan kehendak Tuhan. Maka melakukan perintah dan menjauhi larangan-Nya merupakan tujuan yang dikehendaki Tuhan.

Kedua, maqāṣid al-sharīah diketahui melalui 'illat larangan dan perintah, mengapa suatu perbuatan diperintahkan dan mengapa pula suatu perbuatan lainnya di larang. 'Illat tersebut mestilah diketahui melalui metode-metode yang dikenal dalam literatur ușūl al-fiqh. Jika 'illat tersebut dijelaskan secara eksplisit maka maqāṣid al-sharīah mestilah ditetapkan berdasarkan 'illat tersebut, dan jika tidak diberitahukan maka haruslah tawaqquf (diam) melalui dua sikap yatu: 1) tidak melampaui ketetapan hukum naș; 2) tidak menyatakan sesuatu sebagai maqāṣid al-sharīah terhadap suatu perintah dan larangan.

Ketiga, tujuan syariat dibedakan menjadi dua tujuan, tujuan pokok dan tujuan sekunder, dimana tujuan pokok dapat diketahui dengan cara menggeneralisasikan tujuan sekunder. Tujuan sekunder merupakan sarana penetap bagi tujuan pokok dan sekaligus penguat hikmahnya. Dalam hal ini harus dibedakan antara hukum yang bercorak ibadah dengan hukum-hukum yang bercorak sosial. Dalam ibadah tujuan sekunder tersimpan dalam ibadah itu sendiri, sedang dalam hukum-hukum sosial tujuan sekunder dengan jelas mudah diketahui oleh akal.

Rumusan pokok metode al-Shāțibī di atas, tampak berusaha untuk membedakan beberapa jenis hukum. Dalam kategori perintah dan larangan yang bersifat fundamental dan jelas, di dalamnya tidak terkandung tujuan pokok yang dapat

13 Ibid.

150 || Volume 23, Nomor 2, Oktober 2013

Jurnal Pemikiran Hukum Islam 
diketahui oleh akal manusia kecuali semata-mata untuk dikerjakan dan dijauhi dengan ta'abbud (sikap ketundukan), ${ }^{14}$ karenanya tidak tersedia terapi rasional dan sosiologis terhadapnya. Prinsip tawaqquf al-Shātibī ini ditujukan terhadap aspek perintah dan larangan di atas, dalam hal naș tidak menjelaskan mengapa suatu perbuatan diperintahkan atau dilarang. Kalau dalam kategori selanjutnya, alShāțibī memisahkan hukum 'ubūdiyyāt dan hukum 'àdiyyāt, maka sudah barang tentu yang dimaksudkan dengan terma 'ādiyyāt adalah selain aspek ibadah (ghayru 'ubūdiyyah) yang dalam bahasa Rahman disebut dengan pranata sosial. Dalam aspek sosiaI ini, tujuan pokok syariat (maqāṣid al-sharī’ah) dapat diketahui secara akurat dengan mempertimbangkan tujuan-tujuan sekunder yang disebutkan secara eksplisit, implisit atau yang sarna sekali tidak disebutkan. Tujuan utama tersebut dinamakan dengan al-mașlaḥah al-'āmmah (kemaslahatan umum). Rahman menyebutnya dengan istilah "prinsip keadilan".15

Upaya untuk menemukan tujuan pokok dengan hanya menggunakan generalisasi teoretis terhadap tujuan-tujuan sekunder sebagaimana yang diusulkan oleh al-Shāțibī di atas masih memungkinkan timbulnya bahaya subjektivitas mujtahid. Untuk meminimalisir kekahwatiran tersebut, Fazlur Rahman menambahkannya dengan pendekatan sosio-historis. ${ }^{16}$ Pendekatan ini, akan mengurangi pengaruh subjektivitas mujtahid. Di sisi lain, pendekatan ini akan mempertajam analisis dan memperteguh sikap mujtahid dalam menetapkan aturan (hukum) baru ketika ia berhadapan dengan situasi sosial baru.

\section{Derivasi Maslahat dalam Bangunan Metodologi Ekonomi Islam}

Telah ditegaskan sebelumnya bahwa dalam melakukan ijtihad untuk menghadapi berbagai situasi, maka maslahat harus dijadikan sebagai prioritas utama, karena ia merupakan tujuan pokok syariat (maqāṣid al-sharīah). Dengan merujuk kepada maslahat, fikih atau produk ijtihad yang lainnya dapat disesuaikan dengan kemaslahatan masyarakat.17 Penegasan tentang hal ini penting, karena syariat memuat prinsip-prinsip umum sebagai strategi dasar yang dapat diaplikasikan dalam berbagai kasus dan keadaan. Di samping itu, syariat juga menawarkan

14Fazlur Rahman, Islam (Bandung: Penerbit Pustaka, 2000), h. 152.

${ }^{15}$ Ibid, h. 37.

16Ibid, h. 45.

${ }^{17}$ Amir Muallim dan Yusdiani, Konfigurasi Pemikiran Hukum Islam (Yogyakarta: UII Press, 2001), h. 134.

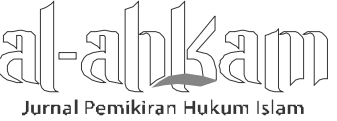

Volume 23, Nomor 2, Oktober 2013 
Syufa'at

konsep fleksibilitas, karena di dalam al-Qur'an tidak ditemukan ketentuan dan materi yang bersifat rinci. Dengan landasan berpikir seperti ini, sebenarnya syariat dapat memberikan kontribusinya bagi kemaslahatan masyarakat tanpa berbenturan dengan norma dan nilai-nilai yang lain. ${ }^{18}$

Semua ulama mengakui bahwa the ultimate goal-nya hukum Islam adalah kemaslahatan. Namun karena semua ulama mempunyai pemikiran yang berbeda antara yang satu dengan yang lainnya tentang maslahat dari sebuah aturan, keadaan yang seperti ini sangat terbuka bagi munculnya subjektivitas pemahaman. Oleh karena itu, untuk kepentingan penderivasian maslahat ke dalam sebuah hukum yang konkret sekaligus untuk pengembangannya, ada baiknya diperhatikan penjenjangan norma-norma hukum Islam. Dalam hal ini terdapat tiga level norma hukum: pertama, norma-norma dasar atau nilai-nilai filosofis (al-qiyām alasāsî]), yakni norma-norma abstrak yang merupakan nilai-nilai dasar dalam hukum Islam seperti kernaslahatan, keadilan, kebebasan dan persamaan, atau pemeliharaan maslahat yang lima (maqāșid al-sharī’ah). Norma abstrak inilah yang disebut sebagai tujuan hukum. Kedua, norma antara (tengah) yang digunakan sebagai perantara (alat) untuk mencapai tujuan-tujuan hukum. Norma tengah ini merupakan doktrin-doktrin umum hukum Islam. Doktrin-doktrin umum ini secara konkret dalam hukum Islam dibedakan menjadi dua macam, yaitu al-nazariyyat alfiqhiyyah (asas-asas umum hukum Islam) dan al-qawā'id al-fiqhiyyah (kaidahkaidah hukum Islam). Ketiga, norma hukum konkret (al-aḥkām al-far'iyyah) sebagai aplikasi dari dua norma sebelumnya. ${ }^{19}$

Ketiga lapisan norma ini tersusun secara hirarkis, dimana norma yang paling abstrak dikonkretisasi atau diejawantahkan dalam norma yang lebih konkret. Misalnya nilai dasar kemaslahatan dikonkretkan antara lain dalam asas umum yang berupa kaidah fiqhiyyah, yaitu antara lain al-mashaqqah tajlïb al-taysìr (kesukaran membawa kemudahan). Asas ini dikonkretkan lagi dalam bentuk peraturan hukum perdata, misalnya orang yang sedang dalam kesulitan dana diberi kesempatan untuk penjadwalan kembali hutangnya. Contoh lain adalah nilai dasar kebebasan diejawantahkan dalam norma tengah, yaitu asas kebebasan berkontrak (mabda' hurriyyah al-ta'āqqud). Asas kebebasan berkontrak ini dikonkretkan lagi

\footnotetext{
${ }^{18} \mathrm{M}$. Umer Chapra, Islam and the Economic Challenge (Leicester: Islamic Foundation: Herndon, Va.: IIIT, 1992), h. 247.

${ }^{19}$ Syamsul Anwar, "Pengembangan Metode Penelitian Hukum Islam", dalam Ainurofiq (ed.), Mazhab Jogja, Menggagas Paradigma Usul Fiqh Kontemporer (Yogyakarta: Ar-Ruz, 1996), h. 157-161. 
dalam bentuk norma konkret, yaitu boleh membuat akad baru apa saja, misalnya akad asuransi, sepanjang tidak melanggar ketertiban hukum syar'i dan akhlak Islam.

\section{Implikasi Maqāṣid al-Sharī’ah terhadap Beberapa Permasalahan Ekonomi}

Implikasi Maqāșid al-Sharīah terhadap permasalahan ekonomi dapat dilihat dari beberapa aspek. Pertama, aspek kesejahteraan sebagai tujuan hidup manusia. Pada dasarnya setiap manusia mempunyai tujuan hidup, yaitu mendapatkan kesejahteraan meskipun masing-masing kelompok berbeda-beda dalam memaknai kesejahteraan tersebut. Secara umum makna kesejahteraan mencakup aspek material dan non-material, akan tetapi masyarakat modern cenderung mamaknai secara parsial. Hal ini menunjukkan bahwa manusia modern mengalami kegagalan dalam merumuskan kesejahtreraan sekaligus mewujudkannya.

Pandangan ekonomi Islam tentang kesejahteraan didasarkan pada pandangan komprehensif tentang kehidupan ini. Kesejahteraan mencakup dua pengertian, yaitu: 1) Kesejahteraan holistik dan seimbang, yaitu mencakup dimensi material dan spiritual serta mencakup individu dan sosial. 2) Kesejahteraan di dunia maupun di akhirat, karena manusia tidak hanya hidup di dunia saja akan tetapi juga di akhirat. Kesejahteraan yang serba mencakup inilah yang diisitilahkan dengan falāḥ. Secara literal, falāh adalah kemuliaan dan kemenangan. Dalam konteks dunia ia merupakan konsep yang multidimensional. Ia memiliki impilikasi pada aspek perilaku individu (mikro) maupun perilaku kolektif (makro). Untuk kehidupan dunia, ia mencakup tiga pengertian, yaitu kelangsungan hidup (survival), kebebasan berkeinginan (freedom from want) serta kekuatan dan kehormatan (power and honour). Sedangkan untuk kehidupan akhirat, falāḥ mencakup pengertian kelangsungan hidup yang abadi (eternal survival), kesejahteraan abadi (eternal prosperity), kemuliaan abadi (everlasting glory) dan pengetahuan yang bebas dari segala kebodohan (knowledge free of all ignorance).

Falāh, dalam arti kehidupan yang mulia dan sejahtera di dunia dan akhirat tersebut dapat diwujudkan apabila terpenuhi kebutuhan-kebutuhan hidup manusia secara seimbang. Terpenuhinya kebutuhan kehidupan masyarakat akan memberikan dampak yang disebut dengan maslahat. Dengan demikian maslahat adalah segala bentuk keadaan baik material maupun spiritual yang mampu meningkatkan kedudukan manusia sebagai makhluk yang paling mulia atau yang dapat memberikan manfaat dan kebaikan. Dalam konteks maqāṣid al-sharīah, maslahat 
sebagai dasar bagi kehidupan manusia adalah terpeliharanya kebutuhan pokok yang lima, yaitu agama, jiwa, akal, keturunan, dan harta. Kebutuhan tersebut merupakan kebutuhan dasar manusia (darūriyyah), yakni kebutuhan minimal yang harus dipenuhi oleh manusia agar hidup sejahtera di dunia dan di akhirat. Jadi, agar manusia memperoleh kesejahteraan, manusia harus memenuhi lima dasar kebutuhan tersebut. Untuk pencapaian tersebut, harus dengan cara memperhatikan kemaslahatan di dunia sekaligus juga akhirat.

Seorang Muslim harus menjalani kehidupannya secara benar, dan menjadikan nilai hidup seseorang menjadi tinggi. Ukuran baik dan buruk diukur dengan melihat sejauhmana manusia berpegang teguh kepada kebenaran,dan inilah yang menjadi ukuran prilaku ekonomi seorang Muslim. Upaya mencapai kesejahteraan, manusia menghadapi banyak persoalan, dimana persoalan tersebut sangat kompleks dan seringkali terkait antara satu faktor dengan faktor yang lain. Permasalahan tersebut adalah adanya kesenjangan (gap) antara sumber daya yang tersedia dengan kebutuhan keinginan manusia dalam rangka mencapai kesejahteraan. Kesenjangan inilah yang mendorong munculnya ilmu ekonomi. Ilmu ekonomi mempelajari upaya manusia untuk mencapai kesejahteraan dengan memanfaatkan sumber daya yang ada.

Perlu ditegaskan bahwa kelangkaan sumber daya bukanlah pangkal masalah ekonomi yang sesungguhnya, karena dunia dan alam semesta ini telah diciptakan oleh Allah untuk mencukupi kebutuhan manusia. Jika manusia mampu memanfaatkan sumber daya serta mengatur kebutuhannya secara bijakasana niscaya tidak akan terjadi problem kelangkaan. Kelangkaan yang terjadi hanyalah bersifat relatif, dalam arti kelangkaan terjadi pada saat tertentu atau pada wilayah tertentu. Kelangkaan relatif ini disebabkan oleh tiga hal pokok yaitu: 1) ketidakmerataan distribusi sumber daya; 2) keterbatasan manusia; 3) konflik antar tujuan hidup dan kepentingan. Peran ilmu ekonorni sesungguhnya adalah mengatasi masalah kelangkaan relatif ini sehingga dapat dicapai kesejahteraan hakiki bagi setiap individu.

Oleh karena itu, ada tiga hal yang perlu dijawab oleh ilmu ekonomi: 1) komoditas apa yang perlu diproduksi untuk merealisasikan falāh. Dalam hal ini, masyarakat harus memutuskan komoditi apa yang harus diproduksi agar mereka menghasilkan maslahat yang maksimum. Maslahat akan menentukan pilihan produksi yang tentunya disesuaikan dengan skala prioritas pada maqāṣid alsharī’ah; 2) bagaimana komoditi diproduksi agar falāh tercapai. Masyarakat harus memutuskan siapa yang akan memproduksi, teknologi apa yang akan digunakan 
dan faktor produksi apa saja yang perlu digunakan agar setiap individu memperoleh falăh; 3) bagaimana falāh didistribusikan agar setiap individu mendapatkan kesempatan yang adil untuk membangun kepribadiannya dan mencapai kesempurnaannya sesuai dengan kemampuannya. Masyarakat harus memutuskan siapa yang berhak mendapatkan pendapatan tinggi dan rendah, siapa yang berhak disubsidi dan siapa yang harus memberikan subsidi materi dan pendidikan, dan sebagainya.

Dapat disimpulkan bahwa permasalahan ekonomi itu adalah apa yang perlu diproduksi untuk memperoleh kemaslahatan tertinggi bagi setiap individu, bagaimana komoditi diproduksi agar kebutuhan setiap individu dapat terpenuhi secara efisien dan adil dan bagaimana falăḥ didistribusikan agar setiap individu memperoleh kesempatan yang adil untuk membangun kepribadian dan mencapai kesempurnaan sesuai dengan kemampuannya.

Kedua, maslahat dalam perilaku konsumen. Persoalan perilaku konsumen Muslim, ilmu ekonomi menekankan pada konsep dasar bahwa manusia cenderung untuk memilih barang dan jasa yang memberikan maslahat yang maksimal. Hal ini sesuai dengan rasionalitas Islam bahwa setiap agen ekonomi ingin meningkatkan maslahat yang diperolehnya. Dalam perilaku konsumsi, konsumen Muslim akan mempertimbangkan manfaat dan berkah yang dihasilkan dari suatu kegiatan konsumsi. Konsumen Muslim merasakan adanya manfaat suatu kegiatan konsumsi ketika ia mendapatkan pemenuhan kebutuhan fisik atau psikis serta material. Di sisi lain, berkah akan ia rasakan ketika mengkonsumsi barang/jasa yang dihalalkan.

Apabila masyarakat menghendaki lebih banyak akan suatu barang dan jasa maka hal ini akan tercermin pada naiknya permintaan. Kehendak seseorang untuk membeli atau memiliki sesuatu bisa muncul karena faktor keinginan atau kebutuhan. Kebutuhan terkait dengan segala sesuatu yang harus dipenuhi agar suatu barang berfungsi secara sempurna. Kebutuhan manusia adalah segala sesuatu yang diperlukan agar manusia berfungsi secara sempurna, berbeda dan lebih mulia dari makhluk lainnya. Baju penutup aurat dan sepatu sebagai pelindung kaki akan menjadikan manusia terhormat dan befungsi dengan sempurna. Di sinilah maqāṣid al-sharīah mengindentifikasikan dirinya.

Di sisi lain, keinginan terkait dengan hasrat atau harapan seseorang yang jika dipenuhi belum tentu akan meningkatkan kesempurnaan fungsi manusia ataupun 
Syufa'at

suatu barang. Keinginan terkait dengan suka atau tidaknya seorang terhadap suatu barang/jasa dan hal ini bersifat subjektif. Secara umum, pemenuhan terhadap kebutuhan akan memberikan tambahan manfaat fisik, spiritual, intelektual maupun material, sedangkan pemenuhan keinginan akan menambah kepuasan atau manfaat psikis di samping manfaat lainnya. Jika suatu kebutuhan diinginkan oleh seseorang, maka pemenuhan kebutuhan tersebut akan melahirkan maslahat sekaligus kepuasan. Namun jika pemenuhan kebutuhan tidak dilandasi oleh keinginan maka hanya akan memberikan manfaat semata. Jika yang diinginkan bukan merupakan suatu kebutuhan maka pemenuhan keinginan tersebut hanya akan memberikan kepuasan saja.

Ajaran Islam tidak melarang manusia untuk memenuhi kebutuhan ataupun keinginannya selama dalam pemenuhannya tersebut martabat manusia bisa meningkat. Semua yang ada di dunia ini adalah untuk manusia. Ia diperintahkan untuk mengkonsumsi yang halal saja secara wajar dan tidak berlebihan. Pemenuhan keinginan atau kebutuhan tetap dibolehkan selama mampu memenuhi maslahat dan tidak mendatangkan mudarat. Jelasnya, ekonomi Islam tidak memerintahkan manusia untuk memenuhi seluruh keinginan dan hasratnya (wants). Memaksimalkan kepuasan akan membawa manusia kepada perilaku individualistik dan tidak peduli dengan lingkungan sosial. ${ }^{20}$ Sebaliknya Islam memerintahkan manusia untuk memenuhi kebutuhannya (needs) sebagai realisasi dari maqāṣid al-sharīah. Hal ini berbeda dengan ekonomi konvensional, ukurannya adalah memaksimalkan utilitas/ keinginan dan kepuasan dengan sumber daya yang ada, sementara Islam memaksimalkan pemenuhan kebutuhan dengan sumber daya yang ada.

Lebih lanjut maslahat dapat dilihat dari kepuasan. Kepuasan adalah suatu akibat dari terpenuhinya suatu keinginan, sedangkan maslahat merupakan suatu akibat atas terpenuhinya suatu kebutuhan atau fitrah. Meskipun demikian, terpenuhinya suatu kebutuhan juga akan memberikan kepuasan terutama jika kebutuhan tersebut disadari dan diinginkan. Berbeda dengan kepuasan yang bersifat individualis. Maslahat tidak hanya bisa dirasakan oleh individu, namun juga bisa dirasakan oleh sekelompok masyarakat. Perekonomian Islam akan terwujud, jika prinsip dan nilainilai Islam diterapkan secara bersama-sama. Pengabaian terhadap salah satunya

${ }^{20}$ M. Fahim Khan, "Theory of Consumer Behavior in an Islamic Perspective", dalam Sayyid Tahir etal. (eds.) Readings in Microeconomic: an Islamic Perspective (Malaysia: Longmann Malaysia, 1992), h. 176.

156 || Volume 23, Nomor 2, Oktober 2013

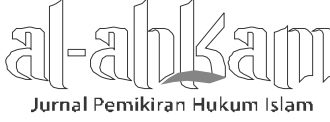


akan membuat perekonomian pincang. Penerapan prinsip ekonomi yang tanpa diikuti oleh pelaksanaan nilai-nilai Islam hanya akan memberikan manfaat (maslahah duniawi), sedangkan pelaksanaan sekaligus prinsip dan nilai akan melahirkan manfat dan berkah atau maslahat dunia dan akhirat.

Konsumen yang menerapkan prinsip kecukupan dalam membeli barang, ia akan membeli sejumlah barang untuk memenuhi kebutuhan minimalnya. Ia akan berusaha semaksimal mungkin untuk memenuhi kebutuhan tersebut tanpa perlu memandang ketersediaan barang bagi orang lain. Manfaat dan berkah hanya akan diperoleh ketika prinsip dan nilai-nilai Islam bersama-sama diterapkan dalam perilaku ekonomi. Sebaliknya jika hanya prinsip saja yang dilaksanakan misalnya pemenuhan kebutuhan, maka akan menghasilkan manfaat duniawi semata. Keberkahan akan muncul ketika dalam kegiatan kosumsi disertai dengan niat dan perbuatan yang baik seperti menolong orang lain dan bertindak adil.

Islam mengakui bahwa maslahat tetap menyisakan ruang subjektivitas, akan tetapi sekurang-kurangnya dapat dikatakan bahwa konsep maslahat lebih objektif dibandingkan dengan konsep utilitas, dengan beberapa alasan sebagai berikut:21 pertama, maslahat memang bersifat subjektif karena setiap individu dapat memutuskan apakah sebuah barang baik atau buruk buat dirinya. Akan tetapi subjektivitas ini bisa diminimalisir dan diarahkan dengan ketentuan-ketentuan pokok tentang aturan konsumsi dalam Islam, yakni halal dan baik. Seorang Muslim tidak akan mengkonsumsi alkohol karena jelas-jelas dilarang oleh agama, dimana larangan tersebut nyata-nyata mengandung maslahat buat manusia, yakni perlindungan terhadap akal. Sementara berdasarkan konsep utilitas, nilai manfaat alkohol sangat relatif, tergantung pada keadaan individu masing-masing.

Ketiga, kemaslahatan individu selalu selaras dan sesuai dengan kemaslahatan sosial. Sebaliknya utilitas individu sering bertabrakan dengan utilitas masyarakat. Dalam Islam, makna kesejahteraan dan kebahagiaan adalah kebahagiaan yang holistik dan seimbang antara individu dan sosial. Manusia memiliki dimensi individu, tetapi ia juga tidak bisa lepas dari lingkungan sosial. Manusia akan merasa bahagia jika terdapat keseimbangan antara dirinya dengan lingkungan sosialnya.

Keempat, konsep maslahat membatasi seluruh kegiatan perekonomian masyarakat. Ia merupakan garis batas yang jelas bagi setiap kegiatan ekonomi, baik yang berhubungan dengan konsumsi maupun produksi atau distribusi. Hal ini

${ }^{21}$ M. Fahim Kahn, “Theory of Consumer Behavior", h. 74.

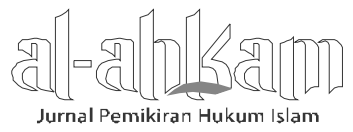

Volume 23, Nomor 2, Oktober 2013 
Syufa'at

tidak seperti ekonomi konvensional dimana utilitas adalah tujuan bagi kegiatan konsumsi dan memaksimalkan keuntungan bagi kegiatan produksi.

Kelima, adalah hal yang mustahil bagi manusia untuk bisa membandingkan antara utilitas seseorang dengan lainnya meskipun mengkonsumsi barang yang sama. Sementara dengan konsep maslahat terbuka kemungkinan untuk itu, sekurang-kurangnya bisa membandingkan tingkat perbedaan maslahatnya. Orang yang melindungi hidupnya dengan mengkonsumsi buah-buahan tentunya berbeda dengan orang yang semata-mata menjaga kesehatannya.

\section{Urgensi Maqāṣsid al-Sharī'ah dalam Ekonomi Islam}

Penemuan-penemuan baru akibat kemajuan ilmu pengetahuan dan teknologi, telah menggeser cara pandang dan membentuk pola pikir yang membawa konsekuensi logis munculnya norma baru dalam kehidupan masyarakat. Maka tidak semestinya kemajuan iptek dan peradaban manusia itu dihadapkan secara konfrontatif dengan naș, akan tetapi harus dicari pemecahannya secara ijtihadi. Dalam banyak hal pada aktivitas ekonomi, Islam memberikan skala normatifnya secara global. Untuk menyebut salah satu contohnya, dapat dikemukakan persoalan aktivitas jual beli dan jaminan hutang piutang. Dalam al-Qur' an hanya disebutkan jual beli yang halal dengan tidak terperinci, umpamanya mana yang boleh ikhtiyar dan yang tidak boleh, dan tidak disebutkan pula cara-cara penjaminan hutang piutang dan hukumnya secara terperinci. Hal-hal yang tidak diatur dalam kedua sumber utama hukum tersebut, diperoleh ketentuannya dengan jalan ijtihad dengan menjadikan konsep maqāṣid sebagai teori dasar dalam pengembangannya, agar umat Islam terdorong aktif, kreatif dan produktif dalam ikhtiar-ikhtiar kehidupan ekonomi mereka. Selama tujuan hukumnya dapat diketahui, maka akan dapat dilakukan pengembangan hukum berkaitan dengan masalah yang dihadapi. ${ }^{22}$

Mengenai aktivitas ekonomi dan bisnis,Islam telah memberikan prinsipprinsip umum yang harus dipegangi, yaitu: ${ }^{23}$ 1) prinsip tidak boleh memakan harta orang lain secara batil; 2) prinsip saling rela, yakni menghindari pemaksaan yang menghilangkan hak pilih seseorang dalam muamalah; 3) prinsip tidak mengandung praktek eksploitasi dan saling merugikan yang membuat orang lain

\footnotetext{
22 Izzuddin ibn 'Abd al-'Aziz ibn 'Abd al-Salām, Qawāid al-Ahkām, h. 201.

${ }^{23}$ Ibn Taymiyyah, al-Qawāild al-Nuraniyyah al-Fiqhiyyah (Lahore: Idārah Tarjuman al-Sunnah, t.th.), h. 255.
} 
teraniaya. Dengan demikian transaksi apapun yang dilakukan oleh para mukallaf tidak boleh bertentangan dengan asas kemaslahatan, dalam arti menimbulkan kerugian (mudarat) atau keadaan memberatkan (mashaqqah). ${ }^{24}$

Aktivitas bisnis kontemporer, jual beli saham misalnya, umat Islam menghadapi berbagai macam karaguan hukum terhadap bisnis ini, terlebih Al-Qur'an dan hadis tidak menjelaskan bisnis ini secara eksplisit. Berkaitan dengan hal ini kaidah ușūliyyah menyatakan "al-aṣlu fi al-'uqūd wa al-mu'āmalāt al-ș̣iḥḥah ḥattā yaqūma al-dalīla 'alā al-buțlan wa al-tahrīm". ${ }^{25}$ Ada juga kaidah lain yang mengatakan al-așlu fi al-ashyā' al-ibāḥah. ${ }^{26}$ Dengan demikian dapat dikatakan bahwa masalah obligasi juga merupakan masalah muamalah baru yang belum pernah ada dan tidak pula dikenal oleh para fuqahö' sebelumnya. Oleh karena itu, hal ini merupakan masalah ijtihādiyyah. Sejalan dengan kaidah-kaidah yang disebutkan di atas, dapat dikatakan bahwa obligasi tersebut adalah boleh sepanjang tidak bertentangan dengan prinsip-prinsip umum dalam muamalah, apalagi jika aktivitas tersebut mengandung maslahat secara individual maupun komunal.

Keberatan terhadap bentuk muamalah selama ini juga terkait dengan masalah capital gain dalam transaksi di pasar sekunder. Di pasar sekunder ini dapat terjadi penjualan dan pembelian, tidak seperti pasar perdana yang hanya melayani penjualan. Harga dalam pasar sekunder ini tidak hanya ditentukan oleh kesepakatan antara perusahaan (emiten) dan underwriter (penjamin emisi), melainkan oleh investor, sehingga harga bisa lebih tinggi dan lebih rendah dibandingkan dengan pasar perdana, sesuai dengan mekanisme pasar. Dengan keadaan ini, bisa terjadi lembaran saham yang dibeli di pasar sekunder akan dijual kepada investor lain (investor spkelulan) dengan suatu harapan akan memperoleh keuntungan yang disebut dengan capital gain, yakni kelebihan harga dari nilai beli saham. Dengan demikian, tujuan investasi telah bergeser dati orientasi laba keuntungan kepada laba spekulatif. Bergeser juga orientasi pembelian saham dari semata-mata penyertaan modal kepada semata-mata jual beli.

Apabila dilihat dari aspek jual beli saja, maka fluktuasi harga saham itu merupakan hal yang wajar dan mubah, sepanjang saham-saham yang diperjual-

\footnotetext{
${ }^{24}$ Syamsul Anwar, "Pengembangan Metode Penelitian Hukum Islam", dalam Ainurofiq (ed.), Mazhab Jogja, Menggagas Paradigma Usul Fiqh Kontemporer, Yogyakarta: Ar-Ruz, 2007), h. 90.

25‘Abd al-Hạīd al-Ḥakīm, al-Bayān (Jakarta: Sa’adiyah Putra, t.th.), h. 230.

26Jalāl al-Dīn al-Raḥmān al-Suyūṭi, al-Ashbah wa al-Naẓāiir. (Beirut: Dār al-Fikr, 1966), h. 82.
}

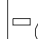

Jurnal Pemikiran Hukum Islam 
Syufa'at

belikan itu bidang usahanya adalah usaha yang mubah. Akan tetapi keuntungan yang diperoleh bisa spekulatif, tidak jarang muncul manuver-manuver tidak sehat yang bisa berwujud konspirasi atau lainnya. Di antara bentuk permainanpermainan tersebut adalah konspirasi antara underwriter, broker dan emiten yang bertujuan agar saham-saham yang ada dapat dipermainkan sesuai dengan keinginan mereka. ${ }^{27}$

Sekelompok pedagang saham menyebarkan berita bohong sekitar perusahaan penerbit saham. Permainan serupa juga bisa dilakukan oleh suatu grup perusahaan atau spekulan agar bisa maraup keuntungan besar. Celaka lagi kalau ada investor yang belum mengerti lika-liku dunia bursa, maka akan menjadi makanan empuk bagi para pialang, misalnya dengan melakukan praktek al-najasī (menggoyang harga). Dapat disimpulkan bahwa jika terjadi motif capital gain, maka terdapat unsur gharar di dalamnya yang dilarang oleh Islam. Sementara gharar adalah sesuatu yang mengakibatkan tidak sahnya sebuah transaksi karena dapat merusak kemaslahatan bagi para pihak.

Di samping itu jual beli saham yang bermotifkan capital gain menempatkan saham tidak berfungsi sebagai bukti penyertaan modal (shirkah) atau investasi (muḍārabah), akan tetapi sudah semacam perdagangan lembaran kertas untuk mengadu nasib dan untung di kemudian hari. Dalam kaitan ini, A.M. Saefudin menyatakan bahwa bursa efek yang Islami tidak diperdagangkan di pasar modal. ${ }^{28}$ Saham merupakan tanda kepemilikan modal perusahaan. Dengan demikian sifat go public yang senafas dengan Islam apabila saham-saham tersebut ditawarkan kepada masyarakat, karyawan dan buruh perusahaan. Di sinilah fungsi kode etik yang dibuat oleh BAPEPAM untuk menghindari kemungkinan-kemungkinan manuver tidak sehat dalam jual beli saham. Penerapan prinsip-prinsip yang terkandung dalam maqāṣid al-sharīah ini, dapat juga dilihat dalam kasus murābahah sebagai salah satu produk primadona perbankan syari'ah, untuk menguji apakah perbankan syari'ah konsisten dengan nilai-nilai maslahat bagi umat atau tidak. Pembahasan ini, sengaja ditempatkan dalam bagian tersendiri dengan tujuan agar lebih fokus pada permasalahan, yakni kritik terhadap perbankan syari'ah ditinjau dari maqāṣid al-sharīah.

${ }^{27}$ Junaedi, Islam dan Bisnis Enterpreunersialisme: Suatu Studi Fiqh Ekonomi Bisnis Modern (Jakarta: Kalam Mulia, 1993), h. 34-35.

${ }^{28}$ Ibid.

160 Volume 23, Nomor 2, Oktober 2013

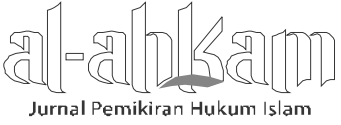




\section{Pembiayaan Murābaḥah dalam Perbankan Syari'ah: Kritik Berbasis Maqāṣid al-Sharīah}

Perbankan, dengan hanya memiliki label syari'ah atau Islam saja berjumlah cukup untuk dapat dikatakan sebagai bank yang benar-benar Islami. Pertama dan utama sekali, lembaga perbankan yang Islami selayaknya perlu menjadi lembaga yang manusiawi, mampu membuat orang memiliki akses kepada dana berdasarkan syarat-syarat yang manusiawi dan dengan biaya yang pantas. Jenis perbankan seperti inilah yang diperlukan untuk membantu meningkatkan standar hidup rakyat di dunia Muslim, yang kebanyakan masih hidup di bawah garis kemiskinan. Namun yang menjadi pertanyaan adalah, apakah sifat-sifat seperti ini benar-benar terdapat pada perbankan syari'ah yang konon dikatakan dijiwai oleh nilai-nilai Islam. Untuk menjawab pertanyaan ini, dapat diajukan masalah murābaḥah sebagai produk perbankan syari'ah/Islam. ${ }^{29}$

Secara umum dapat dikatakan, para teoretisi perbankan Islam menganjurkan bahwa bank Islam seyogianya didasarkan pada bagi hasil daripada bunga. Akan tetapi dalam prakteknya, dijumpai sejak awal bahwa perbankan yang berdasarkan bagi hasil begitu sulit dilaksanakan karena adanya muatan resiko dan ketidakpastian. Keadaan ini mengakibatkan kemunduran secara berangsur-angsur dalam hal pembiayaan murābaḥah menuju pertumbuhan yang mantap di dalam memanfaatkan mekanisme pembiayaan semacam bunga yang diistilahkan dengan murābaḥah. Murābaḥah didefinisikan dengan akad jual beli barang dengan menyatakan harga perolehan dan keuntungan (margin) yang disepakati antara penjual dan pembeli. Secara normatif, si penjual harus memberitahu pembeli tentang harga pembelian barang dan menyatakan jumlah keuntungan yang ditambahkan pada biaya tersebut. Sejak lahirnya dalam hukum Islam, transaksi murābaḥah dimanfaatkan semata-mata untuk tujuan komersial.

Al-Qur'an dan Hadis tidak menyebut secara langsung tentang keabsahan murābaḥah. Imam Malik dan Syafi'i disebut sebagai ulama awal yang mengesahkan bentuk jual beli ini, namun pandangan mereka itu tidak didukung oleh hadis. Hal ini memicu al-Kaff, seorang kritikus kontemporer menyimpulkan bahwa murābaḥah adalah bentuk penjualan yang tidak dikenal pada masa Nabi maupun

\footnotetext{
${ }^{29}$ Abdullah Saeed, Islamic Banking and Interest, a Study of the Prohibition of Riba and Its Contemporary Interpretation (London: Ej. Brill, 1996), h. 146.
}

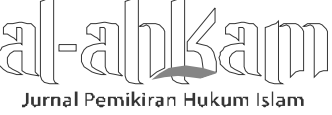

Volume 23, Nomor 2, Oktober 2013 
para sahabatnya. Ulama terkemuka baru mengemukakan pandangannya tentang murābaḥah, pada kuartal pertama abad ke-2 Hijriyah atau bahkan belakangan.

Bank Islam mengadopsi murābaḥah dalam rangka menyediakan pembiayaan jangka pendek kepada nasabah untuk membeli barang-barang meskipun nasabah belum bisa membayar tunai, Ada dua elemen dasar dalam murābaḥah, yaitu harga pembelian dan ongkos yang bertalian dengan pembelian, dan kesepakatan markup. Lebih lengkapnya, ciri-ciri transaksi murābahah (sebagai penjualan dengan pembayaran yang ditangguhkan) adalah: 1) pembeli harus mempunyai pengetahuan tentang biaya-biaya terkait dan tentang harga asli barang dan batas laba (mark-up) harus ditetapkan dalam bentuk presentase dari total harga plus biayabiayanya; 2) yang dijual adalah barang atau komoditas dan dibayar dengan uang; 3) yang diperjualbelikan harus ada dan dimiliki oleh si penjual dan si penjual harus mampu menyerahkan barang itu kepada si pembeli; 4) pembayarannya ditangguhkan.

Murābahah dapat berupa: 1) harga kontan tanpa mark-up sebagai penganti waktu yang diizinkan untuk pembayaran; 2) harga kontan plus mark-up sebagai pengganti waktu diizinkannya untuk pembayaran. Para fuqahä' tidak mempermasalahkan bentuk murābaḥah yang pertama, perbedaan pendapat terjadi pada harga kredit yang lebih tinggi dalam jual beli dengan pembayaran tunda, Maliki dan Syafi'i tidak menyetujui untuk pembayaran tunda dengan harga yang lebih tinggi dan harga yang rendah untuk pembayaran tunai. Meskipun demikian, mereka sepakat dengan kenaikan harga dengan pembayaran tunda adalah boleh, sehingga tidak masalah menjual dengan harga seribu untuk pembayaran tunda dan harga lima ratus untuk pembayaran tunai, dan ini bukan riba dengan syarat si pembeli atau si penjual sepakat terhadap salah satu harga.

Dalam konteks perbankan Islam, beberapa alasan dikembangkan untuk mendukung kebolehan harga lebih tinggi pada penjualan dengan pembayaran yang ditangguhkan, yaitu: 1) teks-teks syari'ah tidak melarang; 2) ada perbedaan antara yang tersedia sekarang dengan tunai dan yang tersedia pada waktu yang akan datang dengan tunai. Berdasarkan 'urf, uang tunai yang diberikan segera lebih tinggi nilainya daripada uang tunai yang diberikan pada waktu yang akan datang; 3) Pertambahan ini tidak berlawanan dengan waktu yang dibolehkan untuk pembayaran. Oleh karena itu tidak menyerupai riba yang diharamkan dalam alQur'an; 4) kenaikan harga dikenakan pada saat penjualan tidak setelah penjualan terjadi; 5) kenaikan harga disebabkan oleh faktor-faktor yang mempengaruhi 
pasar, seperti permintaan dan penawaran dan naik turunnya daya beli uang sebagai akibat inflasi dan deflasi; 6) penjual sedang melakukan suatu aktivitas dagang yang produktif dan diakui. Rafiq al-Misri menambahkan bahwa kenaikan itu merupakan bunga jika terjadi dalam utang piutang. ${ }^{30}$ 7) penjual boleh menetapkan harga berapapun yang dikehendakinya. Argumen-argumen ini selalu diajukan oleh perbankan Islam untuk membenarkan kenaikan harga pada jual beli dengan pembayaran tunda yang secara jelas terkait dengan jangka waktu utang.

Padahal hampir seluruh fuqahä' menyatakan haramnya tambahan yang diterima oleh si penjual dengan dikaitkan dengan waktu, waktu sendiri bukanlah barang, karenanya tambahan seperti ini adalah riba. Kenyataannya, praktek murābaḥah ini telah menjadi praktek baku untuk mengenakan harga yang lebih tinggi dalam jual beli dengan pembayaran tunda selama transaksinya secara eksplisit tidak mengandung tukar-menukar uang dengan uang. Dengan alasan bahwa riba adalah sesuatu yang terjadi terutama pada hutang, yaitu tukarmenukar uang dengan uang.

Sadar dengan adanya kemiripan antara kenaikan harga dalam murābaḥah dengan tambahan yang diberikan kepada kreditur sebagai imbalan perpanjangan waktu jatuh temponya hutang (yang hampir mirip dengan riba dalam al-Qur'an), sebagian pendukung murābaḥah ini berusaha menghindari setiap pengkaitan antara kenaikan harga dalam murābaḥah dengan tenggang waktu untuk pembayaran. Kenaikan harga bagi mereka bukanlah karena tenggang waktunya. Dengan demikian adanya harga yang tinggi untuk pembayaran tunda dengan harga rendah untuk pembayaran tunai tidaklah penting. Yang lebih aneh Iagi, pendapat yang diberikan oleh Kuwait Finance House, kenaikan harga murābahah bukanlah dikarenakan waktu akan tetapi semata-mata karena barangnya. Praktek murābaḥah ini telah dipraktekkan umumnya hampir 75\% dari seluruh kekayaannya, baik di Pakistan, Dubai atau IDB sendiri, ketimbang memberikan skim pembiayaan mudharabah dan musyarakah.

Murābahah sebagai jual beli dengan keuntungan yang ditetapkan di muka, akan tetapi kemudian sikap bank Islam yang enggan mengambil resiko telah mengharuskan modifikasi kontrak murābaḥah menjadi mekanisme pembiayaan yang bebas resiko. Misalnya, sejumlah pilihan yang diberikan oleh fikih kepada

\footnotetext{
30 Rafiq Yūnus al-Misri, Al-Ribā wa al-Fā'idah, Dirāsah Iqtiṣādiyyah Muqāranah (Beirut: Dār al Fikr al-Mu'āṣir, 1999).
}

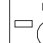

Jurnal Pemikiran Hukum Islam 
pembeli berdasarkan murābaḥah yang tidak menguntungkan bank, telah dihapus secara sistematis karena tujuan-tujuan praktis, telah menjadi metode pembiayaan berdasarkan keuntungan yang ditetapkan di muka. Jika dilihat dari sudut pandang ini, murābahah merupakan salah satu hilah (rekayasa hukum) modern, untuk tidak menyebutnya sebagai tipuan, yang digunakan untuk mempraktekkan utangpiutang berdasarkan bunga, yang mirip dengan bentuk-bentuk serupa yang lebih kasar dari hilah yang dikembangkan dalam fikih masa pertengahan.

Tampaknya bentuk penafsiran atas riba yang telah diterapkan di Perbankan Syari'ah menurut Abdullah Saeed ${ }^{31}$ telah jauh dari sinaran prinsip-prinsip maqāșid al-sharïah seperti kejujuran, keadilan dan kesetaraan sebagai tujuan ditetapkannya hukum haramnya riba. Dari perspektif ini, dalam konteks transaksitransaksi keuangan dan perbankan, faktor keadilanlah yang akhirnya menentukan riba dan bukan riba. Suatu tambahan dalam transaksi keuangan yang diberikan kepada kreditur hanya karena itu adalah semata-mata tambahan tidaklah menjadi riba. Hal ini apabila diterapkan dalam bunga bank modern akan berarti bahwa tidak semua jenis bunga adalah riba kecuali jenis bunga yang mengandung ketidakadilan kepada salah satu pihak yang melakukan kontrak. Dengan demikian setiap transaksi yang berdasarkan bunga yang mengandung ketidakadilan harus diharamkan sebagai riba. Sama halnya, suatu transaksi meskipun tidak secara eksplisit mengandung elemen bunga akan tetapi mengarah kepada ketidakadilan pada salah satu pihak maka bisa dikategorikan sebagai riba.

\section{Kesimpulan}

Sudah menjadi kesepakatan bahwa dengan konsep maqāșid al-sharīah dapat diketahui bahwa maksud dan tujuan Allah dalam memberikan sebuah ketentuan untuk manusia adalah dalam rangka memelihara kepentingan dan kemanfaatan bagi manusia sendiri. Tidak ada ketentuan yang telah ditetapkan kecuali aturan tersebut memang mengandung kemaslahatan buat manusia. Dengan demikian, sejatinya konsep maqāṣid al-sharīah ini bisa dijadikan sebagai blue print dalam menghadapi berbagai permasalahan-permasalahan perekonomian kontemporer baik yang bersifat teoritis maupun praktis. Hal ini semakin beralasan ketika dihadapkan pada realitas ekonomi Islam yang masih mencari bentuk idealnya. [a]

\footnotetext{
31 Abdullah Saeed, Islamic Banking and Interest ..., 1996.
} 


\section{DAFTAR PUSTAKA}

Abd al-Salām, 'Izz al-Dīn ibn 'Abd al-'Azīz, Qawā'id al-Ahkām fi Mașālị̣ al-Anām, t.t.p.: Dār al-Jayl,t.th.

Anwar, Syamsul, "Pengembangan Metode Penelitian Hukum Islam", dalam Ainurofiq (ed.), Mazhab Jogja, Menggagas Paradigma Usul Fiqh Kontemporer, Yogyakarta: Ar-Ruz, 1996.

Arif, Abdul Salam, "Ushul Fiqh dalam Kajian Bisnis Kontemporer", dalam Ainurofiq (ed.), dalam Mazhab Jogja, Menggagas Paradigma Usul Fiqh Kontemporer, Yogyakarta: Ar-Ruz, 1996.

Bakri, Asfari Jaya, Konsep Maqasid asy-Syari'ah Menurut al-Syathibi, Jakarta: Rajawali Pers, 1996.

al-Būṭī, Muḥammad Sa'îd Ramaḍān, Dawābiț al-Maṣlaḥah fi 'l-Sharīah al-Islāmiyyah, Beirut: Dār al-Muttahidah, 1992.

Chapra, M. Umer, Islam and the Economic Challenge, Leicester: Islamic Foundation: Herndon, Va.: IIIT, 1992.

al-Dāraynī, Fatḥ̄, al-Minhaj al-Ușūliyyah fi I jtihād bī 'l-Ra'yi fi Tashrī', Damaskus: Dār al-Kitāb al-Hadīth, 1975.

al-Fāsī, 'Alal, Maqāșid al-Sharī’ah al-Islāmiyyah wa Makārimuhā, t.t.p.: Maktabah alWihdah al-'Arabiyyah, t.th.

al-Ghazālī, Abū Ḥāmid, al-Mustasfā min 'Ilm al-Ușūl, Jedah: Sharīkat al-Madīnah alMunawwarah li al-Tibāah, t.th.

al-Ḥakīm, 'Abd al-Ḥamīd, al-Bayān, Jakarta: Sa'adiyah Putra, t.th.

Ismail, Raji al-Faruqi, Islamization of Knawledge General Principle and Workplan, Brantwood Meryland: International Institute of Islamic Thought, 1402/ 1982.

Junaedi, Islam dan Bisnis Enterpreunersialisme: Suatu Studi Fiqh Ekonomi Bisnis Modern, Jakarta: Kalam Mulia, 1993.

al-Juwaynī, Abū al-Ma'ālī, al-Burhān fi Ușūl al-Fiqhh, Beirut: Dār al-Kutb al-'Ilmiyyah, 1997.

Kahn, M. Fahim, "Theory of Consumer Behavior in an Islamic Perspektive", dalam Sayyid Tahir et.al. (eds.) Readings in Microeconomic: an Islamic Perspektive, Malaysia: Longmann Malaysia, 1992.

Karim, Adiwarman S, Bank Islam, Analisis Fiqh dan Keuangan, Jakarta: Rajawali Pers, 2007.

Manẓūr, Ibn, Lisān al-'Arab, Mesir: Dār al-Mișriyyah li Ta'lïf wa al-Tarjamah, t.th.

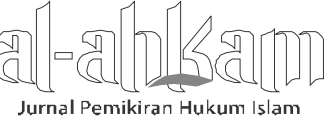

Volume 23, Nomor 2, Oktober 2013 
Syufa'at

Mas'adi, Ghufron A, Pemikiran Fazlur Rahman Tentang Pembaharuan Pemikiran Hukum Islam, Jakarta: Rajawali Pers, 1997.

Mas'ud, Muhammad Khalid, Filsafat Hukum Islam dalam Perubahan Sosial, Terj. Yudian Wahyudi Asmin, Surabaya: al-Ikhlas, 1995.

al-Mișri, Rafiq Yūnus, al-Ribā wa 'l-Fā'idah, Dirāsah Iqtișādiyyah Muqāranah, Beirut: Dār al Fikr al-Mu'āṣir, 1999.

Muallim, Amir dan Yusdiani, Konfigurasi Pemikiran Hukum Islam, Yogyakarta: UII Press, 2001.

Muhammad Hashim Kamali, Prinsip dan Teori-teori Hukum Islam (Ushul Fiqih), terj. Noorhaidi, Yogyakarta: Pustaka Pelajar, 1996.

Mukhtar dkk, Ushul Fiqih I dan II, Yogyakarta, Dana Bhakti Wakaf, 1995.

Mustafa Edwin Nasution, Pengenalan Eksklusif Ekonomi Islam, Jakarta: Perdana Media Group, 2007.

Nasrun, Haroen, Ushul Fiqih, Jakarta: Logos, 1996.

Naqvi, Syed Nawab Haedar, Islam, Economic and Society, London \& New York: Kegan Paul International, 1994.

Rahman, Fazlur, Islam, Bandung: Penerbit Pustaka, 2000.

al-Raisunī, Aḥmad, Nazariyyat al-Maqāṣid 'inda 'l-Imām al-Shațibī, Riyāḍ: Dār al'Ilmiyyah al-Kitāb al-Islāmī, 1992.

Rusli, Nasrun, Konsep Ijtihad al-Syaukani: Relevansinya bagi Pembaharuan Hukum Islam di Indonesia, Jakarta: Logos, 1999.

Saeed, Abdullah, Islamic Banking and Interest, a Study of the Prohibition Of Riba and Its Contemporary Interpretation, London: Ej. Brill, 1996.

Shalțūt, Maḥmūd, Aqīdah wa Sharī’ah, Kairo: Dār al-Qalam, 1966.

al-Shātibī, al-Muwāfaqāt fi Ușūl al-Sharīah, Kairo: Musțafā Aḥmad, t.th.

al-Suyūțī, Jalāl al-Dīn 'Abd al-Raḥmān, al-Ashbah wa 'l-Naẓā'ir, Beirut: Dār al-Fikr, 1966.

Taimiyyah, Ibn, al-Qawāid al-Nurāniyyah al-Fiqhiyyah, Lahore: Idārah Tarjumān alSunnah, t.th.

Wehr, Hans, A Dictionary of Modern Written Arabic, London: Mc Donald \& Evan Ltd, 1980.

Zahrah, Muḥammad Abū, Ușūl al-Fiqh, Mesir: Dār al-Fikr al-'Arabī, 1958.

al-Zuhaylī, Wahbah, Ușūl al-Fiqh al-Islāmī, Damaskus: Dār al-Fikr, 1986.

166 || Volume 23, Nomor 2, Oktober 2013

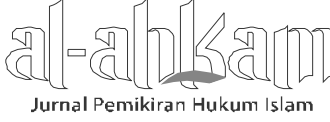

